\title{
Master i selvmordsforebyggende arbeid
}

\author{
Ved Anita Kjølsrud
}

\begin{abstract}
Masterprogrammet i psykososialt arbeid - selvmord, rus, vold og traumer, med studieretning i selvmordsforebyggende arbeid startet opp høsten 2009. Våren 2012 ble de første studentene fra ordinært kull uteksaminert.
\end{abstract}

\section{Masterprogrammet har studenter med grunnutdanning innen barnevern, verne- pleie, psykiatrisk sykepleie og sosialt arbeid. Studenten har erfaring fra praksisfeltet og har fordypet seg i tema som er relevant for egen arbeidsplass og arbeidssituasjon. \\ Våren 2012 ble det blant annet levert masteroppgaver som omhandler barne- vernkuratorers opplevelse av det å miste en klient i selvmord, om bruk av mind- fulness i behandlingsopplegg for suicidale pasienter, om fastlegers tanker og erfarin-} ger med å ta opp selvmord med pasienter og hvordan høyskoleutdannet helsepersonell i DPS-akutteam beskriver selvmordsforebyggende praksis i teamet etter at nasjonale retningslinjer for forebygging av selvmord i psykisk helsevern ble utgitt. Sistnevnte masteroppgave, levert som artikkel skrevet av Per Erik Sørum, ble publisert i forrige nummer av

Suicidologi.

Sørum intervjuet tre akutteam innen DPS med hensikt å utvikle kunnskap om hvordan de nasjonale retningslinjene har påvirket praksis i akutteam i håndtering av selvmordsrisiko. I etterkant av studien ble artikkelen sendt teamene som deltok i unders $\varnothing$ kelsen. Teamene meldte tilbake at det for arbeidsplassen hadde vært en positiv opplevelse å delta i undersøkelsen, at prosessen bidro til $\varnothing \mathrm{kt}$ refleksjon og fokus på rutiner. Det ble også meldt tilbake at funn fra artikkelen ble brukt som utgangspunkt for å endre egen praksis.

Masteroppgavearbeidet gav ikke bare studenten $\varnothing$ kt kunnskap, det bidro også til at både egen arbeidsplass og arbeidsplasser som deltok i studien fikk mulighet til å sette opplæringsbehov og ledelsesforankring på agendaen nok en gang.

$\varnothing \mathrm{kt}$ kompetanse hos helsepersonell er viktig for å bedre kvaliteten på arbeid som utføres. For den enkelte helsearbeider gir $\varnothing \mathrm{kt}$ kompetanse trygghet i egen jobb. I tillegg vil $\varnothing \mathrm{kt}$ kompetanse hos en medarbeider styrke arbeidsplassen som helhet ved at ny kunnskap og entusiasme tilføres.
Generell informasjon:

- 120 studiepoeng

- Deltid over 3 år

- Ukessamlinger

- Individuell veiledning

- Oppstart annen hver høst

- Undervisningssted: Oslo

- Studieavgift: 15000 ,- per semester

- Studiestart: Høsten 2013

\section{Målgruppe:}

Fagpersonell som jobber med selvmord, rus, vold og traumeproblematikk, f. eks. sykepleiere, sosionomer, politi, pedagoger, leger, psykologer og annet tilsvarende fagpersonell.

\section{Opptakskrav:}

Helse- eller sosialfaglig/pedagogisk høyere utdanning av minimum 3 års varighet. I tillegg kreves 2 års relevant yrkespraksis.
Praksisfeltet trenger ildsjeler som tenker nytt og som brenner for sine saker. NSSF har fokus på utdanning nettopp fordi vi trenger fagfolk innen feltet som har en utvidet forståelse for selvmordprosessen og derfor er i stand til å iverksette tiltak både på kort og lang sikt.

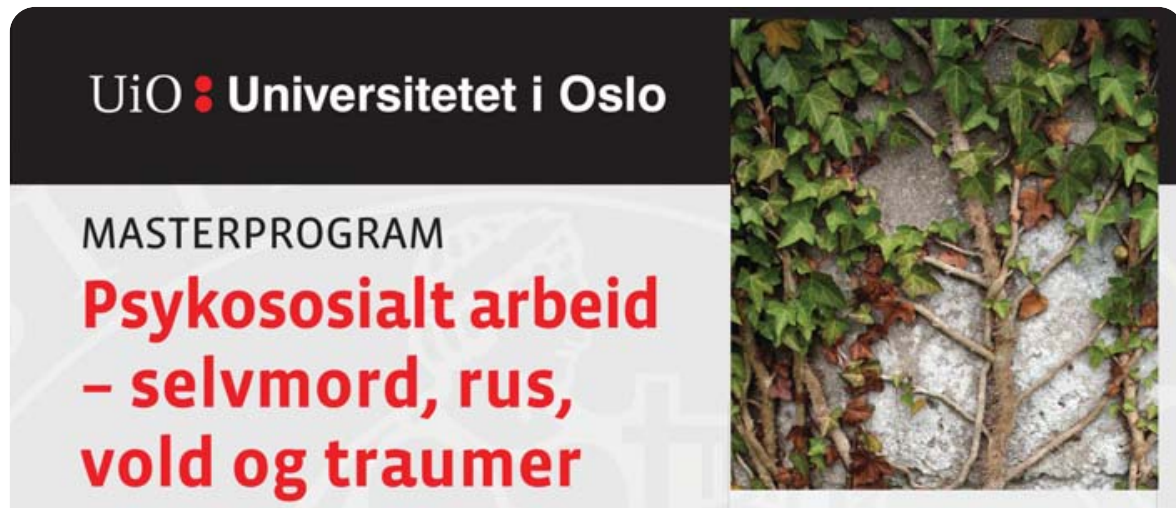

Innhold:

\section{STUDIERETNINGER}

Selvmordsforebyggende arbeid - forståelse av den suicidale prosessen, forebyggingsarbeid, forebygging i klinisk praksis

\section{Rus og - avhengighet}

- behandling og forebygging av rusmiddelproblemer, rus og psykiatri

\section{Vold og traumatisk}

stress - utbredelse, forebygging, intervensjon og behandling

Mål:

Gi kompetanse til å forske og utvikle ny kunnskap, samt å gjennomføre evidensbaserte tiltak rettet mot praksisfeltet.

For mer informasjon om programmet: www.uio.no/studier/program/erf-psykosos-master/

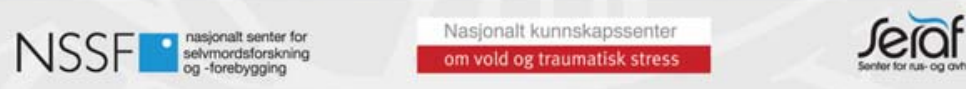

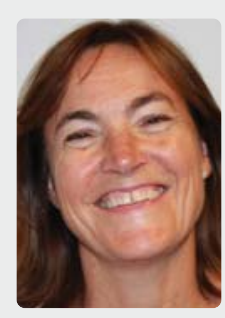

Anita Kjфlsrud er administrativ studieleder med ansvar for koordinering av utdanningsaktivi tetene ved NSSF, blant annet for masterprogrammet i psykososialt arbeid - selvmord, rus, vold og traumer - et samarbeidsprosjekt mellom NSSF, SERAF og NKVTS. 